\title{
Études/Inuit/Studies
}

\section{LAUGRAND, Frédéric and Jarich OOSTEN, 2008 The Sea Woman: Sedna in Inuit Shamanism and Art in the Eastern Arctic, Fairbanks, University of Alaska Press, 152 pages.}

\section{Emily E. Auger}

Volume 33, numéro 1-2, 2009

Éducation et transmission des savoirs inuit au Canada

Education and transmission of Inuit knowledge in Canada

URI : https://id.erudit.org/iderudit/044975ar

DOI : https://doi.org/10.7202/044975ar

Aller au sommaire du numéro

\section{Éditeur(s)}

Association Inuksiutiit Katimajiit Inc.

Centre interuniversitaire d'études et de recherches autochtones (CIÉRA)

ISSN

0701-1008 (imprimé)

1708-5268 (numérique)

Découvrir la revue

Citer ce compte rendu

E. Auger, E. (2009). Compte rendu de [LAUGRAND, Frédéric and Jarich OOSTEN, 2008 The Sea Woman: Sedna in Inuit Shamanism and Art in the Eastern Arctic, Fairbanks, University of Alaska Press, 152 pages.] Études/Inuit/Studies, 33(1-2), 269-272. https://doi.org/10.7202/044975ar d'utilisation que vous pouvez consulter en ligne. 
and relationships between humans and animals in a uniquely Yup'ik way” (p. 343). For this reason, this book is of interest not only to material-culture researchers, but also to anthropologists wish to include material items in their studies of human relations. This book may also be of serious interest to archaeologists for whom material culture is primary research data. It should not be forgotten that archaeologists often tend to minimize the importance of the spirituality and worldview inherent in technology. In this sense, Fienup-Riordan's eloquent publication is a meaningful source for interpretation of material culture, whether for the study of contemporary groups or for the reconstruction of life ways and beliefs of past hunter-gatherers.

\author{
Marie-Pierre Gadoua \\ Department of Anthropology \\ McGill University \\ 855 Sherbrooke Street West \\ Montreal, QC, H3A 2T7, Canada \\ marie-pierre.gadoua@mail.mcgill.ca
}

\title{
LAUGRAND, Frédéric and Jarich OOSTEN
}

2008 The Sea Woman: Sedna in Inuit Shamanism and Art in the Eastern Arctic, Fairbanks, University of Alaska Press, 152 pages.

The publication The Sea Woman exists because of Raymond Brousseau's interest in Inuit art; so, although he is hardly mentioned in the book, this review will begin with him. Brousseau started collecting Inuit art in 1956 when he was only 18 and could ill afford such luxuries. But he continued to indulge his interest to the point that, at age 35, he found that it was really time to open his own gallery in Quebec City. As he puts it, his "addiction" to Inuit art grew worse because he now had opportunities to discover an ever-increasing number of exceptional works and to meet more people who shared his passion (Brousseau, pers. comm. 2009). ${ }^{1}$ The gallery expanded to include three separate locations and in 1998 was finally reorganised into a single building that included a gallery, a storeroom, and a non-profit museum, which operated without government support. Some 100,000 visitors have viewed the permanent and temporary exhibits. The museum has also sponsored travelling exhibits of the Brousseau collection outside the country and has published related catalogues.

John R. Porter, director of the Musée national des beaux-arts du Québec (MNBAQ), was impressed by the development and success of Brousseau's museum and exhibits. He made arrangements with the premier of Quebec and the president of Hydro-Quebec to purchase $50 \%$ of the museum and asked Brousseau to donate the other 50\%. The MNBAQ received 2,635 original and important Inuit works of art and

1 All of the information about Raymond Brousseau, his museum, and his commercial gallery were provided by emailed responses to my queries from Lyse B. Brousseau writing for her husband. Frédéric Laugrand was also very helpful and filled in some of the information on how the book was created and his collaborative work with Jarich Oosten. 
created a permanent gallery to exhibit about 300 exceptional sculptures that attest to some 50 years of dedication to collecting Inuit art. It was with the MNBAQ purchase and donation that the Musée d'art inuit Brousseau closed in 2003, and Raymond and Lyse Brousseau started doing travelling exhibits with their personnel collection, which they call "the second collection." Lyse has some 30 years of experience as a museum designer and was formerly director of exhibits at the MNBAQ. She designed the Brousseau museum and was also invited to create the permanent Inuit gallery at the MNBAQ. Although the museum closed, and Raymond and Lyse have become involved in researching and organising travelling exhibits, the commercial gallery, Galerie Brousseau et Brousseau, whose management Brousseau's son Jean-François took over a few years ago, remains a very active venue for quality Inuit sculptures.

Brousseau's Arctic travels are never intended as "purchasing” trips, but rather as occasions to enjoy the scenery and beauty of the North; perhaps this explains his ongoing attraction to sculptures of strange spirits, whether they seem ugly or beautiful by conventional Western standards, and which he began buying, one example at a time. A number of these items appear in the illustrations of The Sea Woman, which, in spite of Brousseau's involvement in bringing both the book and the collection represented in it into being, is not your "run-of-the-mill let's-pay-homage-to-the-collector" sort of catalogue. The authors, Frédéric Laugrand and Jarich Oosten, bring considerable expertise and experience to the ethnographic approach they take to the project and to the text. However, they downplay not only Brousseau's experience and professional expertise, but their own as well.

Oosten and Laugrand chose 200 works for colour reproductions, which Brousseau arranged for, but only 53 went into the book. They also made recommendations on the placement of the photographs in the text (although not all were followed). The photographs have labels and prose descriptions, but are undated, as is unfortunately common in studies of Inuit art. The text itself begins with a brief preface and a short introduction to the history of shamanism and Arctic art. The subsequent chapters, "The Quest for the Sea Woman," "The Creation of Human Beings and Sea Mammals," "The Descent to the Sea Woman and her House," "Life and Death," "The Sedna Feast, The Tivajuut, and the Ascent of the Sea Woman," and "Transformations," are largely quotations from interviews and accounts gathered in the late 19th and early 20th centuries by such anthropologists as Franz Boas and Knud Rasmussen, as well as statements collected more recently by the authors and others. Commentary from contemporary Inuit artists is primarily in the last chapter. The text makes no specific references to the illustrations and no analysis of the art as such is provided. The intended message, however, is that Sedna is a figure of long and considerable importance in Inuit oral traditions and shamanistic practices, as well as in recent visual art, particularly the element of transformation.

Most of the textual material has been chosen for its connection to Sedna and related shamanistic practices and, as such, is fascinating reading material. However, readers should be cautioned about the tendency for such anthologies to inadvertently overstate the uniformity and continuity of beliefs in the Arctic, an effect that is emphasised by footnotes and references. Which is not to say that Inuit cultures do not 
possess homogeneities and continuities, only that their nature in the expansive, geographically unique Arctic environment is easily lost to an academic writing style. Likewise for the artwork titles, which may overstate the subject. Or perhaps it is more accurate to say that they direct the viewer to emphasise the personage, where the art, as well as the ethnographic material, suggest that the real underlying subject is transformation. As Frédéric Laugrand (pers. comm. 2009) notes, "The Sedna references in the titles are never from us, we just kept all the original titles and subtitles that [came] from many sources. This is always problematic, but [it is] very informative to see how Sedna is mentioned everywhere by Inuit artists, coop managers, and curators in museums.”

Transformation, as the authors insist, is the most clearly identifiable and geographically consistent theme of the material here, as well as in many other kinds of Inuit art. This theme runs through the entire text and is one of the most widespread concepts underlying Inuit understanding of reality, regardless of the specifics of tales and narratives about Sedna or shamanism. Where Sedna herself may, at times, seem to have become a literary trope for "goddess," the illustrations in the book tell otherwise. Transformation in literature may be metaphor; transformation in visual art is made "real."2 Yet this theme finds its way into titles only rarely, with difficulty, and by way of labels and captions that merely point to this or that influence. It is left for the viewer to "see" that the image is meant to be understood as reality, not as a token of some abandoned and mythologised past.

For such material, the proper Western literary counterpart is Metamorphosis, by the Roman author Ovid (43 BC-17 AD). His book is a collection of inter-related poems, usually rendered in English as a series of short stories. In it, as in many Inuit narratives, transformation is the substantive subject matter, but it is articulated through specific stories and characters: various immortals take on non-human form at will and subject humans to similar transformations as both punishment and reward. As in shamanistic belief and practice, alterations in size and mass are common. For example, after a devastating flood, humankind is recreated when two survivors toss stones behind them on an oracle's advice. The stones grow and take on human form and acquire characteristics totally unrelated to their original existence. Metamorphosis became a major source for Western visual artists in search of details and elements that would likely appeal to viewers of their work. These elements, which include werewolves, vampires, the phoenix, and more, have become the basis of a widely shared and readily recognisable collection of cultural narratives and characters, although perhaps few adults take time to contemplate these realities as anything more than whimsies. The Inuit diverge from such Western aesthetics by making the fantastic truly "real." This realism is the principal reason for illustrating ethnographic texts with contemporary art in books, such as The Sea Woman, destined primarily for Western readers.

2 As Graburn (1974-1975: 67) noted, Inuit carvers throughout the Canadian Arctic "like to do things that are sulijuk, truthful or realistic - that is that they look like what they are meant to be, even if the mental model (thing in the mind) is non-material such as a spirit, myth or dream." 


\title{
References
}

GRABURN, Nelson

1974-75 Some Problems in the Understanding of Contemporary Inuit Art, Western Canadian Journal of Anthropology, 4(3): 66-72.

\author{
Emily E. Auger \\ Independent Scholar \\ Ontario, Canada \\ augere@canada.com
}

SONTAG, Natascha

2007 Carte Inuktitun Inuit Nunanginni Kanatami. The Inuit Language in Inuit Communities in Canada. La langue inuit dans les communautés Inuit au Canada, Fairbanks, University of Alaska Press.

Cette carte de Natascha Sontag est sans aucun doute beaucoup plus qu'une simple carte géographique. Des informations figurent au recto comme au verso du document, ce qui impliquera - avis aux intéressé(e)s désireux de l'afficher sur un mur -, d'en acheter au moins deux exemplaires! Sontag s'est probablement inspirée de la remarquable carte Inuit Nunait, publiée en 1995 par l'Alaska Native Language Center, mais son produit final est original et bien réussi.

Au recto, Sontag présente une carte détaillée des langues de l’Arctique canadien. L'auteure a d'abord dessiné les quatre grandes régions de cet espace immense en y faisant figurer de nombreux dialectes perceptibles à l'échelle locale ou régionale. Sur le plan visuel, la présence de nombreux toponymes en syllabique, en inuktitut romain et en anglais, mais aussi des noms de langues et d'autres termes géographiques ne rend pas la lecture très commode. Cet inconvénient comporte toutefois un avantage en ce qu'il oblige le lecteur à se concentrer sur le document. Dès lors, l'information paraît très riche, d'autant plus que Sontag y fait figurer des données statistiques sur les populations et les langues, une légende détaillée et même un exemplaire complet du syllabaire.

Trois critiques peuvent cependant être formulées. D'une part, je ne suis pas pleinement convaincu de toutes les divisions qui sont proposées, en ce sens qu'elles donnent une image très statique des langues et des dialectes du monde inuit, alors que les populations et les parlers sont souvent très diversifiés. Certaines communautés comme Iqaluit ou Arviat comportent en fait plusieurs sous-ensembles où les mélanges sont inévitables. Ici, et en dépit du fait que l'auteure indique les communautés plurilinguistiques par des cercles barrés, on a encore parfois l'impression d'avoir affaire à des ensembles perméables. N'étant ni linguiste ni géographe, j’ignore comment ce défi aurait pu être relevé, mais je pense qu'il faut demeurer très prudent face à cette carte, au risque de croire à tort qu'il n'y aurait que des ensembles homogènes. La présence de l'anglais et du français n’apparaît pas davantage. Les 